Ewa Jarosz

https://doi.org/10.26881/pwe.2019.47.01

ORCID:0000-0002-3207-0148

Uniwersytet Śląski w Katowicach

ewa-jarosz@us.edu.pl

\title{
„Zakazuje się stosowania kar cielesnych”. I co dalej? Nowoczesne strategie eliminacji przemocy $w$ wychowaniu
}

\author{
Summary \\ „Corporal punishment is banned." So what next? \\ Contemporary strategies of eliminating violence in child-rearing
}

The paper presents the evidence based practice approach to eliminate violence against children. Here, the official ban of all forms of violence is seen as a very effective and needed means. But on the other hand, the ban is seen as a first step, because other activities are needed to eliminate corporal punishment. Today actions often come from analyses of effective practice. The paper presents main foundations of the modern strategies to stop corporal punishment, coming from the analysis of one example of such an initiative - the international cooperation that aimed at finding out effective practice in several countries in Europe where the ban has been already introduced.

Keywords: violence in upbringing, corporal punishment, ban of corporal punishment, child protection

Słowa kluczowe: przemoc w wychowaniu, kary cielesne, zakaz kar cielesnych, ochrona dziecka

\section{Wprowadzenie. Zero tolerancji dla przemocy w wychowaniu}

Praktyki wychowawcze wykorzystujące przemoc od wieków były „naturalnym” sposobem postępowania z dziećmi (Jarosz 2008: 80-88). Są więc niemal „wrośnięte” w życie społeczne i obyczajowość, do niedawna w zasadzie nie budziły krytycznej refleksji, a pojawiające się głosy, głównie postępowych myślicieli i pedagogów, np. Rousseau czy później Montessori, Foerstera, Claparedego, Korczaka, były nieliczne (Jarosz 2008; Jarosz, Michalak 2018). Dopiero w ostatnich dekadach kary cielesne i inne zachowania przemocowe w wychowaniu zaczęły przykuwać większą uwagę badaczy oraz osób zaangażowanych w ochronę praw dzieci. W stosunkowo krótkim czasie nastąpiła więc istotna zmiana poziomu krytyki kar cielesnych: od kontestowania sposobów ich wykonywania do całkowitego ich zanegowania oraz traktowania jako problemu społecznego, który musi zostać wyeliminowany. 
Kary cielesne nadal są problemem powszechnie występującym w różnych regionach świata. Dowodzą tego liczne raporty i badania, w których są podawane dane o dzieciach doświadczających kar - niekiedy problem dotyczy trzech czwartych populacji (zob. np. Pinheiro 2006; UNICEF 2014; Know Violence in Childhood 2017; SRSG VAC 2017; Riedl i in. 2019). Jednocześnie badania nad ich wpływem, zwłaszcza te prowadzone w ostatnich dekadach, pokazują dewastujące konsekwencje dla rozwoju dzieci (Paolucci, Violato 2004; Larzelere i in. 2005; Ferguson 2013; Gershoff 2013; Gershoff, Grogan-Kaylor 2016; Afifi i in. 2017; Pace i in. 2019), w tym obejmujące zmiany w budowie i funkcjonowaniu mózgu (Strauss i in. 2009; Tomoda i in. 2009; Teicher i in. 2016). Te ustalenia znacząco wzmocniły głosy osób lobbujących za całkowitą eliminacją przemocy wobec dzieci. Na całym świecie milkną dzisiaj dysputy na temat skuteczności kar cielesnych oraz polemiki na temat możliwości ich stosowania w imię jakichś celów wychowawczych. Nikt nie stawia już pytania o to, czy kary fizyczne mogą być stosowane czy nie. $\mathrm{W}$ tej sprawie zarówno naukowe, jak i polityczno-społeczne gremia dają jednoznaczną odpowiedź - kary cielesne i wszelkie formy przemocy muszą być wyeliminowane (Know Violence in Childhood 2017; UNICEF 2017; Hillis i in. 2018). Obecnie świat zastanawia się nad tym, jak je skutecznie wyeliminować.

Konceptualizacja kierunków i rodzajów działań na rzecz eliminacji przemocy w wychowaniu opiera się z jednej strony na badaniach i ustaleniach na temat uwarunkowań występowania problemu, a z drugiej na analizach doświadczeń różnych podmiotów i środowisk działających w zakresie eliminacji przemocy oraz wyłanianiu w ten sposób efektywnych skutecznych praktyk (Gershoff $\mathrm{i}$ in. 2017). W niniejszym opracowaniu proponuję przyjrzeć się tej właśnie strategii konceptualizacji działań, opartej na idei ewaluacji i wyłaniania tzw. dobrych praktyk, często określanej jako evidence based strategy, czyli strategia oparta na dowodach.

\section{Evidence based practice, czyli dzialanie oparte na dowodach - przede wszystkim prawny zakaz!}

Różne instytucje, środowiska i społeczeństwa zdobyły bardzo bogate doświadczenie w zakresie działań - programów i środków ograniczania, wręcz eliminacji przemocy wobec dzieci. John Leventhal (2001) już niemal dwie dekady temu oceniał je jako ogromny kapitał, który daje możliwość podejmowania działań w każdych warunkach kulturowych, społecznych i ekonomicznych. Analizy praktyki są przeprowadzane na poziomie lokalnym, regionalnym, krajowym, a także międzynarodowym. Są one efektem bardziej lub mniej rzetelnych metodologicznie badań naukowych. Widoczne są w konkretnych opracowaniach naukowych, ale też często w obszernych raportach dotyczących problemu przemocy, przygotowywanych przez krajowe oraz międzynarodowe agendy lub inicjatywy. Szczególnie te ostatnie zawierają analizy praktyki eliminacji przemocy wobec dzieci wykorzystywane w różnych krajach i na tej podstawie rekomendują określone rozwiązania, działania, programy czy środki (zob. np. SRSG VAC 2013; Know Violence in Childhood 2017; Butchart $i$ in. 2018). 
W tych badaniach i analizach wskazuje się przede wszystkim, że podstawowym działaniem eliminującym przemoc wobec dzieci w wychowaniu są prawne reformy, w tym wprowadzenie całkowitego zakazu kar cielesnych. Prowadzone analizy wykazują, że wprowadzenie prawnego zakazu wszelkiej przemocy, a zwłaszcza wyraźnego zakazu stosowania kar cielesnych we wszelkich środowiskach, w tym w rodzinie, któremu towarzyszą również inne działania, przyczynia się do postępującej zmiany postaw wobec kar cielesnych i ich wykorzystywania w wychowaniu. Taka jest też - jak podkreślają eksperci - jego główna funkcja, tj. zmiana postaw społecznych wobec kar cielesnych w postaci eliminacji ich aprobaty oraz w ten sposób - eliminacja ich stosowania (Henry $\mathrm{i}$ in. 2018). Badania nad zmianami w postawach i praktyce wykorzystywania kar cielesnych, konsekwentnie dokumentujące skuteczność zakazu, były przeprowadzane i nadal trwają w Szwecji. Od momentu obowiązywania zakazu stosowanie kar cielesnych spadło $\operatorname{tam}$ z 35\% do 2\% (Janson i in. 2017; Janson 2018). Podobną sytuację zaobserwowano w Finlandii, w której w 2017 r. aż 95\% obywateli wiedziało o istnieniu zakazu, podczas gdy zanim go wprowadzono w 1983 r., 50\% społeczeństwa uważało, że kary cielesne to aprobowany prawnie sposób wychowywania dzieci. Co więcej, Finlandia szczyci się dzisiaj niemal zerowym odsetkiem rodziców stosujących klapsy wobec swoich dzieci. Znacząco maleje też w tym społeczeństwie stosowanie innych rodzajów kar cielesnych. Badania wskazują, że np. odsetek dzieci, które doświadczyły ciągnięcia za włosy przez rodziców, spadł z 65\% w 1988 r. do 16\% w 2017 (Janson 2018).

Również badania porównawcze, prowadzone w kilku krajach, z których jedne wprowadziły zakaz kar cielesnych, a inne nie, wykazały skuteczność tego instrumentu w kwestii zmiany postaw - znacząco obniżały poziom aprobaty dla takich zachowań (Bussmann $\mathrm{i}$ in. 2009; Global Initiative... 2018a, 2018b).

W Polsce, która wprowadziła całkowity zakaz kar cielesnych w 2010 r., także odnotowuje się spadek społecznej aprobaty przemocy w wychowaniu (Jarosz 2015, 2017; Jarosz, Michalak 2018). Według danych z 2018 r. społeczna aprobata przemocy w wychowaniu spadła w przypadku tzw. klapsów z $78 \%$ przed wprowadzeniem zakazu do $43 \%$, a na temat tzw. lania z 41\% do 24\% (Jarosz, Michalak 2018).

Efektywność zakazu oraz międzynarodowa presja, aby go wprowadzić, m.in. działalność Specjalnego Reprezentanta ONZ ds. przemocy wobec dzieci, oraz promocja zakazu za pomocą dokumentów, np. Europejskiej Rekomendacji 1666 (zob. Jarosz, Michalak 2018: 333-336) spowodowały, że do dzisiaj przepis ten zastosowały już 54 państwa, a 56 kolejnych wyraziło już zgodę na jego wprowadzenie do swojego systemu prawa (zob. Global Initiative... 2018a).

\section{Zakaz... i co dalej? Nowoczesne strategie eliminacji przemocy w wychowaniu}

Doświadczenie wszystkich państw, które wprowadziły zakaz, wskazuje, że jakkolwiek skuteczność tego środka jest niepodważalna, nie jest wystarczająca do osiągnięcia eliminacji problemu. Szczycące się największym sukcesem Szwecja czy Finlandia pokazują, 
że istotne były także inne działania, jakie podejmowano w celu wzmocnienia funkcjonalności zakazu i jego społecznej implementacji. Wymienia się: kampanie społeczne czy edukację rodziców, działania wsparcia socjalnego dla rodzin oraz organizowanie sieci placówek wsparcia opiekuńczo-wychowawczego rodzin, a także działania podnoszące kompetencje profesjonalistów (Janson i in. 2017). Oznacza to, że poza zakazem istotne są kolejne kroki wdrażające zakaz przemocy w wychowaniu w życie społeczne. Pojawia się więc pytanie: co dalej. Odpowiedzi starają się dostarczać różne inicjatywy, często międzynarodowe, ukierunkowane na analizę i identyfikowanie rozwiązań, programów, metod i środków działań na rzecz eliminacji przemocy w wychowaniu. Wydają się one szczególnie cenne, ponieważ opierają się na mocnym kapitale - ekspertach i doświadczeniach wielu różnych państw.

Przykładem takiej inicjatywy był międzynarodowy projekt „Dzieciństwa bez przemocy; w kierunku eliminacji kar cielesnych w Regionie Morza Bałtyckiego"1. Pozwolił on na wypracowanie dosyć zwartej koncepcji eliminacji kar cielesnych na podstawie podejścia evidence based practice w państwach nadbałtyckich, z których niemal wszystkie wprowadziły prawny zakaz ich stosowania. Ta koncepcja eliminacji kar cielesnych została w znaczącym stopniu ukierunkowana na profilaktykę i wczesną prewencję problemu. Oparta jest na prawie czterdziestoletnim doświadczeniu związanym z wprowadzeniem zakazu prawnego oraz realizacji innych działań przez niektóre państwa biorące udział w tej inicjatywie. Celem stało się wypracowanie opartej się na międzynarodowej kooperacji badaczy i ekspertów, spójnej, wielostronnej strategii zarówno profilaktyki i wczesnej prewencji przemocy w wychowaniu, jak i promowania pełnego wdrożenia w praktykę wychowawczą prawnego zakazu kar cielesnych. W ramach projektu opracowano raporty dotyczące poszczególnych krajów partnerskich, ukazujące stan legislacji, badań i głównych działań $\mathrm{w}$ zakresie problemu kar cielesnych ${ }^{2}$. Ponadto przedstawiono bogaty zestaw rekomendacji ukierunkowanych na eliminację przemocy w wychowaniu w postaci kilku tematycznych przewodników (podręczników) na temat wdrażania zakazu (są one dostępne pod adresem: http://www.childrenatrisk.eu/nonviolence). Opracowania te ukazują różne sfery działań profilaktycznych wobec problemu przemocy w wychowaniu. Prezentują kluczowe informacje i wskazują najlepsze praktyki, które wykazują skuteczność w eliminacji kar cielesnych. Każdy z przewodników koncentruje się na określonym obszarze dotyczącym eliminacji przemocy w wychowaniu. Ponadto kolejnym efektem wspomnianej inicjatywy

1 Projekt był prowadzony przez Children at Risk Unit Council of the Baltic Sea States w latach 20172018, finansowany przez Komisję Europejską we współpracy podmiotów z różnych państw: Ministerstwa Spraw Społecznych Estonii, Ministerstwa Spraw Społecznych i Zdrowia Finlandii, Ministerstwa Opieki Społecznej Łotwy, Rzecznika Praw Dziecka w Polsce (w kadencji 2013-2018) oraz Ministerstwa Zdrowia i Spraw Społecznych Szwecji. Międzynarodowym partnerem projektu była organizacja Global Initiative to End All Corporal Punishment of Children (www.endcorporalpunishment.org). Autorka pełniła funkcję krajowego koordynatora projektu w Polsce.

2 Raport dotyczący Polski National Consultation in Poland jest dostępny na stronie: http://www.childrenatrisk.eu/nonviolence/wp-content/uploads/sites/3/2018/05/NVC-National-Consultation-Poland-Report-.pdf. 
międzynarodowej kooperacji „Dzieciństwa bez przemocy” jest kampania edukacyjna na temat kar cielesnych, która jest skierowana do rodziców, dzieci, praktyków, a także decydentów czy innych osób (zob. http://www.childrenatrisk.eu/nonviolence/comic).

Analiza rekomendacji, uwag i komentarzy oraz konkretne informacje i wskazania organizowanych działań pozwalają stworzyć obraz podstawowych założeń, na których powinny się opierać nowoczesne strategie eliminacji przemocy w wychowaniu (zob. Henry $i$ in. 2018). Są one z jednej strony owocem analityczno-badawczego podejścia do istniejącej praktyki, a z drugiej uwzględniają rezultaty badań naukowych nad uwarunkowaniami występowania przemocy wobec dzieci.

Podstawowym założeniem nowoczesnych strategii jest stanowisko, że postawy wobec wykorzystywania kar cielesnych można zmieniać. Wykazały to liczne badania, w tym te prowadzone w krajach skandynawskich, które były już przytaczane, polskie oraz porównawcze w kilku krajach europejskich (Bussmann i in. 2009; Janson i in. 2017; Jarosz, Michalak 2018). Skutecznymi narzędziami zmiany są nie tylko zakazy prawne, które oczywiście odgrywają podstawową rolę, ale także reformy w sferze polityki rozwoju społecznego oraz rozwoju społeczeństwa demokratycznego. Te bowiem zmierzają do zmian sposobu traktowania i spostrzegania dzieci w społeczeństwie i różnych środowiskach społecznych w kierunku uznawania dzieci za osoby (oraz grupę społeczną), którym należą się równe traktowanie wobec prawa, a także inne prawa równościowe. Okazuje się bowiem, że w krajach, które mogą się poszczycić znaczną redukcją poziomu wykorzystywania kar cielesnych, np. we wspominanej Szwecji, obok ustanowienia zakazu podjęto wiele działań na rzecz podnoszenia świadomości istoty i znaczenia praw dziecka (Janson i in. 2017).

Do podstawowych założeń nowoczesnych strategii eliminacji przemocy w wychowaniu należy również uznanie, że rolą wprowadzanych zakazów kar cielesnych jest jednoznaczna ochrona dzieci oraz że zakaz jest wprowadzany w interesie dzieci, a nie przeciwko komuś lub przeciw czyimś prawom, jak niestety przedstawiają to często grupy opozycyjne wobec zakazu (Jarosz, Nowak 2012: 171-173). Dzisiaj wyraźnie podkreśla się, że głównym celem zakazu nie jest ściganie sądowe, ale jego normotwórcze działanie oraz realizowanie społecznej edukacji o niewłaściwości takiego postępowania z dziećmi. Ponadto zakaz umożliwia i ułatwia realizowanie działań wspierających rodziców, opiekunów i inne osoby opiekujące się dziećmi i je wychowujące. Reformom prawa i skuteczności zakazu, jego urzeczywistnianiu w praktyce służy jasny plan działania co do sposobów, które należy podejmować w celu podniesienia społecznej wiedzy o nim oraz świadomości na temat rzeczywistej roli zakazu i prawa jako takiego w ochronie dzieci przez przemocą (Henry i in. 2018).

Niezwykle istotnymi elementami nowoczesnych strategii eliminacji przemocy w wychowaniu są porozumienie różnych stron sceny politycznej oraz wspólny, zawiązany ponad politycznym interesem partyjnym front wsparcia dla sprawy eliminacji kar cielesnych. Chodzi tu nie tylko o zredagowanie jasnych, wyraźnych przepisów chroniących dzieci przed wszelką przemocą, ale też o opracowanie narodowych planów działań, 
narodowych strategii eliminacji przemocy wobec dzieci. Powstawaniu takich narodowych planów czy strategii sprzyja rozumienie wspólnej odpowiedzialności, a także wyraźne określenie ról podmiotów działających na różnych poziomach społecznych. Nawoływania do tworzenia takich narodowych programów, rozumianych jako zintegrowane strategie działań w kierunku eliminacji problemu przemocy wobec dzieci, przyjmują postać konkretnych dokumentów, np. Zalecenie Komitetu Ministrów Rady Europy w sprawie zintegrowanych strategii narodowych ochrony dzieci przed przemocą (Jarosz, Nowak 2012; Jarosz, Michalak 2018: 337-386).

Warunkiem funkcjonalności nowoczesnych strategii eliminacji przemocy w wychowaniu, czyli rzeczywistej społecznej implementacji zakazu, jest odpowiednie finansowanie działań na poziomie krajowym i lokalnym (Know Violence in Childhood 2017). Także $w$ tej kwestii niezbędne jest porozumienie różnych stron politycznych w kraju. Adekwatne finansowanie strategii wdrożenia zakazu kar cielesnych wskazuje się jako krytyczny czynnik skuteczności i funkcjonalności prawa ochrony dzieci przed przemocą. W tym względzie międzynarodowe agendy formułują stanowcze zalecenia (np. SRSG VAC 2013; WHO 2014).

W nowoczesnych strategiach eliminacji przemocy w wychowaniu przyjmuje się, że skuteczność w osiąganiu tego celu opiera się w ogromnym stopniu na spójnej oraz trafnej edukacji spolecznej na temat zakazu kar cielesnych. Podnosi ona rozumienie sensu i roli zakazu w społeczeństwie oraz przyczynia się do wzrostu jego społecznego poparcia. Pomaga też rozwijać świadomość znaczenia gwarantowania dzieciom wolności od wszelkich form przemocy. Kluczowe przesłanie edukacji społecznej na temat kar cielesnych powinno pokazywać je jako niedopuszczalne metody oddziaływania na dziecko oraz wyjaśniać, że są one szkodliwe dla rozwoju dziecka i jego późniejszego funkcjonowania. Edukacja taka powinna też upowszechniać metody pozytywnego rodzicielstwa i promować je jako przynoszące korzyści zarówno dzieciom, jak i rodzicom, a także całemu społeczeństwu. Skuteczne postaci i formy takiej edukacji zostały wypracowane i rekomendowane (zob. Haldorsson 2018).

W budowaniu nowoczesnych strategii eliminacji przemocy wobec dzieci należy też przyjąć założenie, że oprócz ogólnospołecznej edukacji realizowanej na przykład kampaniami społecznymi to specjaliści pracujący $z$ dziećmi i rodzinami $\mathbf{w}$ różnych sektorach i obszarach pelnią kluczową funkcję w promowaniu zakazu przemocy w wychowaniu oraz promowaniu jego właściwego rozumienia. To profesjonaliści w obszarze socjalnym, zdrowotnym, oświatowym i innych mają możliwości najefektywniej wyjaśniać rodzicom, opiekunom i samym dzieciom sens i rolę zakazu. Profesjonaliści mogą też odpowiednio reagować w sytuacjach spotykania się w swojej praktyce z tym problemem. Sprzyja temu ustanowienie formalnego obowiązku reagowania dla tych profesjonalistów - przepis ten występuje w nowoczesnych strategiach eliminacji przemocy. Profesjonaliści jednak potrzebują wsparcia w tej roli. To oznacza konieczność organizowania dobrych szkoleń i innych form rozwijania ich kompetencji po to, aby oni sami właściwie pojmowali rolę i znaczenie zakazu oraz rozumieli swoje powinności, a także 
możliwości w zakresie ochrony dzieci. Wśród profesjonalistów szczególny nacisk kładzie się na takie zawody, jak pracownicy socjalni, nauczyciele, pracownicy wymiaru sprawiedliwości i organów ścigania, pracownicy służby zdrowia, ponadto podkreśla się ogromną wagę działania innych służb czy instytucji. Podnosi się też znaczenie władz państwowych oraz lokalnych, a także innych podmiotów funkcjonujących w społeczności lokalnej. Podkreśla się wręcz rolę całego społeczeństwa obywatelskiego, w tym organizacji pozarządowych, charytatywnych, wyznaniowych i innych w walce z problemem przemocy w wychowaniu (INSPIRE 2016).

Jako że jest dostępny szeroki wachlarz działań oraz możliwych podmiotów ich realizacji, w nowoczesnych strategiach eliminacji przemocy w wychowaniu zwraca się uwagę, że dobra skuteczność działań wymaga istnienia wyrazistej międzysektorowej koordynacji. To pozwala bowiem na sprawną realizację tych działań, które są priorytetowe, m.in. chodzi o upowszechnienie działań edukacyjnych oraz prewencyjnych. Dobra koordynacja działań w obrębie instytucji rządowych oraz pomiędzy nimi a podmiotami społeczeństwa obywatelskiego, a także monitorowanie i ewaluacja tej koordynacji są kluczowe w skutecznym wdrażaniu zakazu kar cielesnych. Spostrzega się, że wielodyscyplinarna i międzyinstytucjonalna współpraca jest w zasadzie niezbędnym czynnikiem dla działania w wymiarze wczesnej identyfikacji przemocy w wychowaniu oraz prewencyjnego objęcia danej sytuacji (rodziny) pomocą, wsparciem psychosocjalnym czy innymi działaniami (Henry, Lenihan 2018).

Ważnym założeniem nowoczesnych strategii eliminacji kar cielesnych jest traktowanie profilaktyki kar cielesnych oraz sprawnego funkcjonowania całego systemu ochrony dzieci jako działań ukierunkowanych przede wszystkim na zapobieganie separacji rodzinnej, tj. oddzielenia dziecka od rodziny (Henry i in. 2018). Zidentyfikowanie istnienia problemu przemocy w wychowaniu w rodzinie powinno oznaczać, że dobro dziecka, które jest rozumiane w perspektywie jego szczególnych cech i potrzeb, musi być podstawowym kryterium determinującym działania interwencyjne oraz że separacja dziecka powinna być zastosowana tylko w sytuacjach, kiedy jest niezbędna do zapewnienia mu bezpieczeństwa (INSPIRE 2016). W sytuacjach, gdy separacja jest konieczna, szczególnie istotnym czynnikiem skuteczności działania jest społeczne zaufanie do działających w tym względzie na poziomie lokalnym oraz ogólnospołecznym - służb. To zaufanie może być rozwijane dzięki takim przymiotom działania służb, jak przejrzystość, wiarygodność, odpowiedzialność oraz bezstronność w rozpatrywaniu przypadków przemocy wobec dziecka, a także dzięki podejmowaniu najlepszych dla dobra dziecka dalszych działań (Wenke 2018).

W nowoczesnych strategiach eliminacji kar cielesnych silną pozycję zajmują badania naukowe. Dostarczają one nie tylko obrazów epidemiologicznych na temat samego problemu czy ukazują uwarunkowania jego występowania, ale także dostarczają dowodów na coraz powszechniejsze zastosowanie się do zakazu bądź nie. Co więcej, rzetelne badania nie tylko ukazują sam rozwój społecznej implementacji zakazu, ale także są istotne dla analiz dotyczących efektywności wprowadzanych środków czy programów eliminacji kar cielesnych. 
Biorąc pod uwagę ogromne znaczenie badań naukowych dla eliminacji przemocy w wychowaniu, niezwykle istotną rolę odgrywają dobre funkcjonalne systemy gromadzenia danych oraz metodologicznie wiarygodne procedury monitorowania zmian postaw społecznych i zachowań wobec dzieci. Rzetelne badania surveyowe są wskazywane jako podstawowe (Janson 2018). Podkreśla się przy tym, że wskaźniki i źródła danych na temat problemu oraz działań wobec niego powinny być dezagregowane, tj. gromadzone w perspektywie różnych grup dzieci, w tym dzieci wykluczonych, a także na tle różnych cech (np. płeć, niepełnosprawność, mniejszość etniczna, dzieci z obszarów niekorzystnych socjalnie) i powinny mieć zróżnicowany charakter. Istotne są dane dotyczące zarówno zgłaszanych przypadków, jak i postaw społecznych wobec kar cielesnych oraz ich dynamiki. Ważne przy tym jest, aby dane pochodziły nie tylko od rodziców, ale także od samych dzieci. Ważnym rodzajem danych są również te dotyczące doświadczeń rodziców na temat różnych usług wsparcia rodziny oraz eliminacji występowania w niej przemocy w wychowaniu (Janson 2018).

Jako ostatnie, choć nie mniej ważne w ramach przedstawianej charakterystyki nowoczesnych strategii eliminacji kar cielesnych należy wymienić wskazanie, by strategie i działania tworzyć i realizować, opierając się na zasadzie partycypacji dzieci. Co oznacza, że konceptualizacja kierunków działań, wybór strategii i form działania powinny być wypracowywane wspólnie z dziećmi, w porozumieniu z nimi oraz z uwzględnieniem pomysłów i wyborów dzieci w sprawie sposobów działania oraz monitorowania ich efektów (SRSG VAC 2013; Henry i in. 2018).

\section{Końcowy akcent - zamiast podsumowania}

Współczesny świat nie zadaje już dzisiaj pytań o to, czy kary cielesne są skuteczną oraz dopuszczalną metodą wychowania. Stanowisko w tej kwestii jest jednoznaczne. Ugruntowane imperatywem demokratyzacji życia oraz równościowego traktowania dzieci i ich prawnej ochrony, a także (a dla niektórych zwłaszcza) niezbitymi już obecnie argumentami dowodzącymi ich rozwojowej szkodliwości. Obecnie nie należy się zastanawiać nad tym, czy eliminacja przemocy w wychowaniu jest konieczna, ani też nad tym, czy jest możliwa. Odpowiedź na oba te pytania jest jednoznaczna - tak! Dzisiaj stawiane jest pytanie o to, jakie działania są najbardziej skuteczne i czasowo efektywne. Należy również rozważyć, jak sprawić, aby społeczeństwo, a co najważniejsze - jego rządowe przedstawicielstwo zrozumiało wagę tego problemu oraz chciało przeznaczyć odpowiednie środki i siły na walkę z nim, a także podjąć trud organizowania odpowiednich działań. Wiadomo już, że muszą to być rozległe oraz konsekwentne działania o wielorodzajowym, wielopoziomowym charakterze. A to oznacza, że są one kosztowne. Potrzebne są więc ponadpolityczna ugoda i dobra wola $w$ finansowaniu działań eliminujących przemoc wychowaniu. Konieczna jest również ponadpolityczna wola budowania zintegrowanych narodowych programów działań. Silną barierą dla skutecznej ochrony dzieci przed przemocą nie jest bowiem, jak to zauważył już wiele lat temu Richard Krugman (1999), 
bezsilność, ale niekorzystna społeczna atmosfera dla takich działań oraz brak politycznej woli i mobilizacji. Bez społeczno-politycznego zaplecza eliminacja przemocy w wychowaniu ma dużo mniejsze szanse na spełnienie.

\section{Literatura}

Afifi T., Ford D., Gershoff E.T., Merrick M., Grogan Kaylor A., Ports K., MacMillan H., Holden G., Taylor C., Lee S., Bennett R.P. (2017), Spanking and adult mental health impairment: The case for designation of spanking as an adverse childhood experience. „Child Abuse and Neglect”, 71.

Bussmann K., Ethal C., Shroth A. (2009), The effect of banning corporal punishment in Europe: five nation comparison. Halle-Wittenberg, Martin-Luther-Universität Halle-Wittenberg.

Butchart A., Hillis S., Burrows S. (2018), INSPIRE: Using the best evidence to prevent violence against children. W: G. Lenzer (ed.), Violence against children. New York, Routledge.

Ferguson C.J. (2013), Spanking, corporal punishment and negative long term outcomes: A meta-analytic review of longitudinal studies. „Clinical Psychology Review”, 33.

Gershoff E. (2013), Spanking and child development; we know enough now to stop hitting our children. „Child Development Perspectives”, 7(3).

Gershoff E.T., Grogan-Kaylor A. (2016), Spanking and child outcomes. Old controversies and new meta-analyses. ,Journal of Family Psychology”, 30(4).

Gershoff E.T., Leeb S.J., Durrant J.E. (2017), Promising intervention strategies to reduce parents' use of physical punishment. „Child Abuse \& Neglect”, 71.

Global Initiative to End All Corporal Punishment of Children (2018a), Ending legalised violence against children by 2030: Progress towards prohibition and elimination of corporal punishment in Pathfinder countries, http://endcorporalpunishment.org/wp-content/uploads/thematic/Pathfinders-report-2018-singles.pdf, 20.05.2019.

Global Initiative to End All Corporal Punishment of Children (2018b), Working towards universal prohibition of corporal punishment: A special report for the high level global conference held by H.E. the President of Malta, May-June 2018, http://endcorporalpunishment.org/wp-content/ uploads/global/Special-report-2018-Malta-spreads.pdf, 20.05.2019.

Haldorsson O. (2018), Building supportive societies for non-violent childhoods. Stockholm, Council of the Baltic Sea States.

Henry A., Lenihan T. (2018), Ensuring non-violent childhoods. Stockholm, Council of the Baltic Sea States.

Henry A., Lenihan T., Global Initiative to End All Corporal Punishment of Children (2018), A Step by step guide on implementing the Convention on the Rights of the Child to achieve an end to corporal punishment. Stockholm, Council of the Baltic Sea States Secretariat.

Hillis S., Mercy J.A., Kress H., Butchart A. (2018), Violence against children: Endemic, Detrimental, Preventable. W: G. Lenzer (ed.), Violence against children. New York, Routledge.

INSPIRE (2016), https://www.who.int/violence_injury_prevention/violence/inspire/en/, 10.04.2019.

Janson S. (2018), Tracking progress towards non-violent childhoods. Measuring changes in attitude and behavior to achieve an end to corporal punishment. Stockholm, Council of the Baltic Seat States.

Janson S., Langberg B., Svensson B. (2017), Physical punishment of children banned since 30 years: The Swedish experience. New York, Routledge. 
Jaros P. (2012) (oprac.), Prawa dziecka. Dokumenty Rady Europy. Warszawa, Biuro Rzecznika Praw Dziecka.

Jarosz E. (2008), Ochrona dzieci przed krzywdzeniem. Perspektywa globalna i lokalna. Katowice, Wydawnictwo Uniwersytetu Śląskiego.

Jarosz E. (2015). Przemoc w wychowaniu. Między prawnym zakazem a społeczna akceptacją. Warszawa, Biuro Rzecznika Praw Dziecka.

Jarosz E. (2017), Prawo dziecka do życia wolnego od przemocy. „Dziecko Krzywdzone”, 16(2).

Jarosz E., Michalak M. (2018), Bicie dzieci - czas z tym skończyć. Kontestacja kar cielesnych we współczesnym świecie. Warszawa, Biuro Rzecznika Praw Dziecka.

Jarosz E., Nowak A. (2012), Dzieci ofiary przemocy w rodzinie. Warszawa, Biuro Rzecznika Praw Dziecka.

Know Violence in Childhood (2017), Ending Violence in Childhood; Global Report 2017. New Delhi, Know Violence in Childhood.

Komentarz Ogólny Nr 8 Komitetu Praw Dziecka ONZ (2013). W: P. Jaros (oprac.), Prawa Dziecka. Dokumenty ONZ. Warszawa, Biuro Rzecznika Praw Dziecka.

Krugman R.C. (1999), The Politics. „Child Abuse and Neglect”, 10(23).

Larzelere R.E., Kuhn B.R. (2005), Comparing child outcomes of physical punishment and alternative disciplinary tactics: A meta analysis. „Clinical Child and Family Psychology Review”, 8. http://dx.doi.org/10.1007/s10567-005-2340-z, 10.11.2018.

Leventhal J.M. (2001), The prevention of child abuse and neglect; successfully out of the blocks. „Child Abuse and Neglect”, 4(25).

National Consultation in Poland, http://www.childrenatrisk.eu/nonviolence/wp-content/uploads/ sites/3/2018/05/NVC-National-Consultation-Poland-Report-.pdf, 2.04.2019.

Pace G.T., Lee S.J., Grogan-Kaylor A. (2019), Spanking and young children's socioemotional development in low- and middle-income countries. „Child Abuse and Neglect”, 88.

Paolucci E.O., Violato C. (2004), A meta-analysis of the published research on the affective, cognitive, and behavioral effects of corporal punishment. „The Journal of Psychology”, 138. http:// dx.doi.org/10.3200/JRLP.138.3.197-222, 11.11.2017.

Pinheiro P.S. (2006), World report on violence against children. Geneva, United Nations. https:// www.unicef.org/violencestudy/reports.html, 10.04.2019.

Riedl D., Beck T., Exenberger S., Daniels J., Dejaco D., Unterberger I., Lampe A. (2019), Violence from childhood to adulthood: The influence of child victimization and domestic violence on physical health in later life. „Journal of Psychosomatic Research”, 116.

SRSG VAC (2013), Toward a world free from violence. Global survey on violence against children. New York, Office of the Special Representative of the Secretary General on Violence against Children.

SRSG VAC (2017), Annual report of the Special Representative of the Secretary-General on Violence against Children. $\mathrm{http}: / /$ srsg.violenceagainstchildren.org, 10.10.2017.

Strauss M., Paschall M.J. (2009), Corporal Punishment by mothers and development of children's cognitive ability: a longitudinal study of two nationally representative age cohorts. „Journal of Aggression, Maltreatment \& Trauma", 18(5).

Teicher M., Samson J.A., Anderson C.M., Ohashi K. (2016), The effects of childhood maltreatment on brain structure, function and connectivity. „Nature Reviews Neuroscience”, 17. 
Tomoda A., Suzuki H., Rabi K., Yi-Shin S., Polcari A., Teicher M.H. (2009), Reduced Prefrontal Cortical Gray Matter Volume in Young Adults Exposed to Harsh Corporal Punishment. „Neuroimage", 47 (supl. 2).

UNICEF (2014), Hidden in Plain sight. A statistical analyses of violence against children. New York, UNICEF. https://reliefweb.int/sites/reliefweb.int/files/resources/Hidden_in_plain_sight_ statistical_analysis_EN_3_Sept_2014.pdf, 10.04.2019.

UNICEF (2017), Child is a child. Protecting children on the move from violence, abuse and exploitation. https://www.unicef.org/publications/files/UNICEF_A_child_is_a_child_May_2017_EN.pdf, 13.04.2019.

Wenke D. (2018), Service providers as champions for non-violent childhoods. Stockholm, Council of the Baltic Sea States.

WHO (2014), Investing in children: the European child maltreatment prevention action plan 20152020. http://www.euro.who.int/_data/assets/pdf_file/0009/253728/64wd13e_InvestChildMaltreat_140439.pdf, 20.05.2019. 